\title{
Toxicity assessment of heavy metals and organochlorine pesticides in freshwater and marine environments, Rosetta area, Egypt using multiple approaches
}

\author{
Muhammad A. El-Alfy' ${ }^{1}$ Amany F. Hasballah² ${ }^{2}$ Hazem T. Abd El-Hamid ${ }^{1}$ and Ahmed M. El-Zeiny ${ }^{3 *}$
}

\begin{abstract}
Egypt faces a rapidly increasing deterioration of its surface water owing to the discharges of contaminated effluents. The present study focuses on assessing the levels of toxic heavy metals and organochlorine pesticides (OCPs) in water, sediments and Phragmites australis of freshwater and marine environments at Rosetta area. Fourteen sites were sampled including 4 sites within the marine environment and 10 sites distributed along the Rosetta River Nile. Potential sources of pollution were spatially assessed using remote sensing and geographic information system techniques. To quantify the environmental impact of metals on the aquatic system, metal index (MI) in freshwater, heavy metal pollution index, and ecological risk index (Er) in sediments as well as bioaccumulation factor (BAF) in $P$. australis were calculated. Remote sensing results showed that drainage canals $(954.8 \mathrm{~km})$, cultivations $\left(1252.4 \mathrm{~km}^{2}\right)$ and urbanized zones $\left(88.6 \mathrm{~km}^{2}\right)$ are the major sources of contamination in the studied area. Results of MI indicated that water of the Rosetta area was moderately affected by the metal pollution. Er values for metals in the investigated sites showed low potential ecological risk $(<40)$. High values of Er were observed in coastal marine water and the nearby estuary. OCPs in water and sediment samples were below the detection limits. Mean $\mathrm{Ni}$ and $\mathrm{Co}$ concentrations of metals in P. australis were higher than the critical limits of these ions. Results of BAF and regression analysis recommend using $P$. australis in remediation of metals from the aquatic system in such settings worldwide. The present study shows that using integrated remote sensing and chemical analyses could provide a regional and cost-effective assessment tool of environmental toxicity in fresh-saline water interface.
\end{abstract}

Keywords: Metal, Pesticides, Toxicity, Remote sensing, Mediterranean Sea, Rosetta River Nile

\section{Introduction}

Environmental pollution is mainly anthropogenic, associated with industrial development as all wastewaters either from industrial or agricultural activities drained into water bodies with low or no treatment [1]. These wastes negatively influence both freshwater and marine environments [1]. The River Nile, which is considered as the main fresh water source for the western side of the Nile Delta, receives a huge amount of wastewater. Regularly during winter closure period, Idfina barrage releases water to the Mediterranean Sea [2].

\footnotetext{
*Correspondence: narss.ahmed@gmail.com

${ }^{3}$ Environmental Studies Department, National Authority for Remote Sensing and Space Sciences, Cairo 1564, Egypt

Full list of author information is available at the end of the article
}

Metal pollutants are mainly produced by industries, petroleum sectors and sewage dumping [3]. Environmental contamination by metals is given a broad interest because of its toxicity, persistence, and accumulation in organisms. Further, agricultural activities release considerable amounts of metals to the environment [4].

On the other hand, organochlorines have been involved in reproductive and immunological defects observed in marine animals. Anthropogenic organochlorines have been considered a severe threat to health of the marine environment. This threat is arisen from their strong accumulation in lipid tissues of marine biota as well as their toxicity to marine organisms and additionally their slow degradation [5].

Persistent organic pollutants are characterized by their persistence and bio-accumulative characteristics and 
include several first-generation organochlorine insecticides such as dieldrin, DDT, toxaphene, chlordane and some industrial chemicals or by-products including polychlorinated biphenyls, dibenzo-p-dioxins (dioxins), and dibenzo-pfurans (furans). The continuous use of large quantities of these compounds, owing to environmental persistence, has the ability to magnify bioaccumulation and biomagnification problems. These contaminants accumulate in fatty tissues and the first exposure in humans happens in the fetus when a percentage of the maternal 'burden' of accumulated toxins is transported across the placenta [6].

Remote sensing and Geographic Information System (GIS) have been widely used in environmental assessment studies. Remote sensing imagery can be processed to identify and map the potential water pollution sources. Many studies addressed the relations between land use type and water quality deterioration (e.g., $[7,8])$. Commonly, urban and agricultural activities have a great impact on water resources. Environments nearby the agricultural and industrial activities are more subject to pollution than remote areas [8].

Multiple land uses and anthropogenic activities (i.e., urban, industrial, agricultural, recreational and shipping) exist in the Rosetta area of Egypt. These activities increase the pressure on the environmental resources including river and marine environments. Therefore, some studies have been conducted on this area to assess water quality by using sampling strategy and analytical methods. For instance, Elhaddad and Al-Zyoud [9] investigated total dissolved solids (TDS), electric conductivity (EC), alkalinity, ammonia, biological oxygen demand (BOD), chloride, and sulfate in this area and found all parameters exceeded the acceptable limits as a result of pollution. Additionally, water quality index was investigated using statistical analysis and the results showed that fecal coliform represents the main reason for the poor water quality in the Rosetta region [10].

Moreover, a two-season monitoring study has confirmed that water quality in the Rosetta area is significantly impacted by wastewater discharge [11]. The study recorded high levels of ammonium, TDS, EC, BOD, alkalinity, turbidity and a noticeable decline in the dissolved oxygen level.

The present study implements an integrated approach incorporating data from multiple sources (i.e., remote sensing, in-situ, lab analyses, GIS and field observations) to assess heavy metals and pesticides in various environmental components along Rosetta area, Egypt. This paper aims at assessing three toxic heavy metals in water and sediment as well as determining the bioaccumulation factor (BAF) of Phragmites australis using integrated remote sensing and chemical analyses. The $P$. australis is a common weed present in the studied area. Also it can grow in contaminated sites and has a high BAF. Therefore, its potentiality for the accumulation of the toxic metals based on the obtained results will be also tested. The paper also aims to assess the organochlorine pesticides (OCPs) in the collected water and sediment samples.

\section{Materials and methods}

\section{Study area}

The study area is located in the northern Nile Delta of Egypt. It represents the downstream area of the River Nile, Rosetta branch. The area covers the region between Kafr El-Zayat city and the Mediterranean Sea (Fig. 1). The Rosetta branch of the River Nile receives drainage water from cultivated agricultural lands containing fertilizers and other chemicals. Further, it receives industrial wastes from Malaya, Salt, and Soda companies at Kafr El-Zayat. Likewise, it receives agricultural wastewater enriched by the animal composite where an increase in phytoplankton was observed [11, 12].

\section{Remote sensing and GIS analyses}

A space-borne medium spatial resolution Landsat OLI image, synchronized with the sampling time, was subjected to radiometric and atmospheric correction to calibrate the data using ENVI 5.3 Software. The calibrated images in integration with high spatial resolution online WorldView-2 imagery were processed to identify the potential source of pollution in the study area (i.e., urban areas, vegetation and drains). The urban and agricultural areas were extracted from the supervised classification (i.e., Maximum Likelihood Classifier) applied on the calibrated image. Further, a vegetation density map was produced based on the Normalized Difference Vegetation Index yielding the following classes; no vegetation, sparse, moderate and dense vegetation. Crops were located in the moderate and dense vegetation classes whereas the sparse density class represents the naturally growing vegetation. Likewise, the on-screen digitizing technique was utilized to update and map irrigation and drainage networks in the study area using ArcGIS 10.4.1.

\section{Water and sediment sampling}

Twenty-eight samples of water and sediment (14 of each) were collected from the Mediterranean Sea and the River Nile of Rosetta during August 2017. Water samples were collected into $1000 \mathrm{~mL}$ acid-washed polyethylene bottles then transported to the laboratory and stored at $4{ }^{\circ} \mathrm{C}$ for further analysis. The sediment samples were air dried in room temperature $\left(25^{\circ} \mathrm{C}\right)$ for 10 to $15 \mathrm{~d}$, then ground, sieved in $0.5 \mathrm{~mm}$ sieve and stored for analysis.

\section{Heavy metals determination \\ Water samples}

According to the American Public Health Association (APHA) [13], pH of $200 \mathrm{~mL}$ water sample was adjusted to 2-3 by adding drops of $1 \mathrm{M} \mathrm{HNO}_{3}$. Then, $10 \mathrm{~mL}$ nitric acid was added, digested and finally aspirated into Atomic Absorption Spectrophotometer (AAS) Perkin-Elmer double beam 2380. The equipment was used with adapted PerkinElmer hollow-cathode lamps and conventional $10-\mathrm{cm}$ slot burner head for an air-acetylene flame to read the absorb-

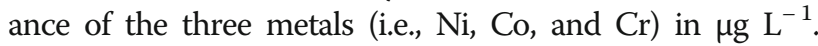




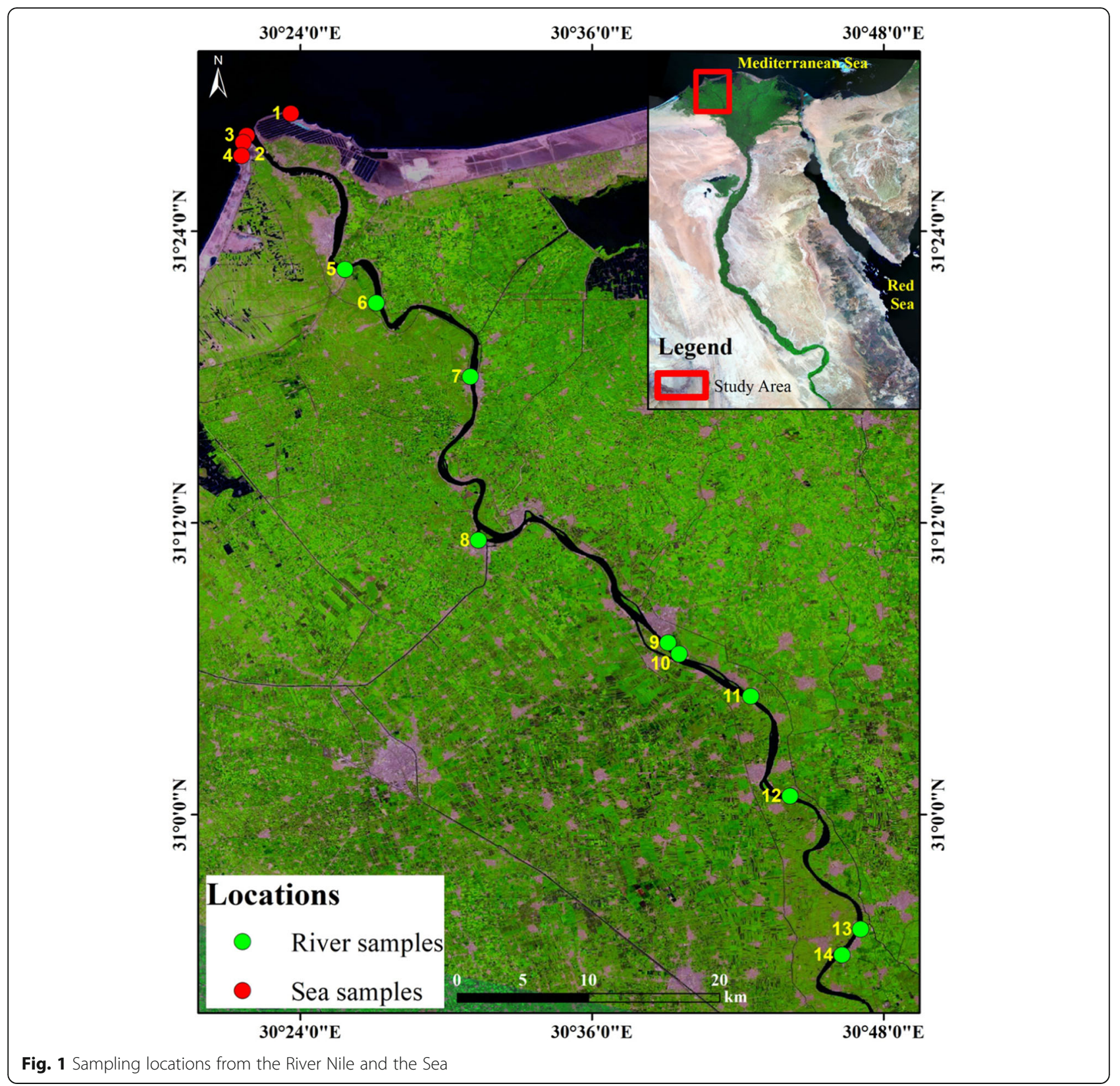

Several metal indices will be used in the present study to assess pollution. Description of these indices is illustrated in Appendix 1.

Heavy metal pollution index (HPI) HPI is a mathematical approach of ranking that provides the composite impact of an individual metal on the overall quality of water. Its ranking ranged from zero to one and gives an indication of the relative importance of individual quality considerations and inversely proportional to the recommended standard $(\mathrm{Si})$ for each parameter. The HPI determination involves the weight calculation of the $i^{\text {th }}$ parameter; the quality rating for each heavy metal and sub-indices summation in the overall index [14]. The unit weight of the $\mathrm{i}^{\text {th }}$ parameter $\left(\mathrm{W}_{\mathrm{i}}\right)$ is illustrated in Eq. (1).

$$
W_{i}=\frac{K}{S i}
$$

Where $\mathrm{S}_{\mathrm{i}}$ is the standard value for the parameter, $\mathrm{K}$ is a constant of proportionality. Rating of individual quality is calculated as Eq. (2).

$$
Q_{i}=100 * \frac{V i}{S i}
$$

Where $\mathrm{Q}_{\mathrm{i}}$ represents the sub-index of the parameter, $V_{i}$ represents the observed value of the parameter in $\mu \mathrm{g}$ 
$\mathrm{L}^{-1}, \mathrm{~S}_{\mathrm{i}}$ is the allowable limit for the parameter. HPI is calculated as Eq. (3).

$$
H P I=\sum_{i=1}^{n} W_{i} * \frac{Q i}{W i}
$$

Since $Q_{i}$ represents the sub-index of the $i^{\text {th }}$ parameter and $\mathrm{n}$ is the number of parameters considered. The critical contamination index value is 100 .

Metal index (MI) MI is calculated as illustrated in Eq. (4) as suggested by Caeiro et al. [15].

$$
M I=\sum\left(\frac{C i}{M A C i}\right)
$$

Where MAC is the maximum permissible levels and $C_{i}$ is the average level of each metal. Increase of metal concentration more than MAC levels indicates deteriorated water quality. MI value greater than 1 is a warning threshold limits [16].

\section{Sediment samples}

Sediment samples were air dried, sieved and digested within a mixture of $3 \mathrm{~mL}$ nitric acid $\mathrm{HNO}_{3}, 2 \mathrm{~mL}$ perchloric acid $\left(\mathrm{HClO}_{4}\right)$ and $1 \mathrm{ml}$ hydrochloric acid $(\mathrm{HCl})$, as described by Oregioni and Astone [17]. After digestion (nearly $2 \mathrm{~h}$ ), the digested medium was filtered and diluted using deionized distilled water to a fixed volume for measuring the three toxic metals $(\mathrm{Ni}, \mathrm{Co}$, and $\mathrm{Cr}$ ) using ASS, the results were expressed as $\mu \mathrm{g} \mathrm{g}^{-1}$.

The ecological risk assessment of heavy metals in sediment was calculated using two risk indices viz. potential ecological risk index (RI) and pollution load index (PLI). The RI was developed as Eqs. (5) and (6) of others $[14,18]$.

$$
\begin{aligned}
& R I=\sum_{1}^{n} E r \\
& E r=\operatorname{Tr} * C F
\end{aligned}
$$

Where Er is the single index of the ecological risk factor, $\mathrm{n}$ is the count of the heavy metal species, $\operatorname{Tr}$ is the toxic response factor suggested by Hakanson [18] for the three metals; $\mathrm{Co}$ (5), $\mathrm{Ni}$ (5) and $\mathrm{Cr}$ (2).

Contamination Factor (CF) and PLI were developed through Eqs. (7) and (8). The categories of these indices are described in Appendix 1.

$$
C F=\frac{\text { Cmetal }}{\text { Cbackground }}
$$

$$
P L I=(C F 1 * C F 2 * C F 3 * \ldots \ldots \ldots . . C F n)^{1 / n}
$$

Where $\mathrm{n}$ is the count of the elements.

\section{Plant samples}

A total number of 14 sites was surveyed where one sample each of water, sediment and $P$. australis was collected from each site. A total of 14 water and 14 sediment samples were analyzed for heavy metals and pesticides content. However, for $P$. australis, three representative composite samples were generated (sites 1, 2 \& 3) representing area nearby the Sea (north), estuary (middle), and fresh (south) environments.

$P$. australis was collected from the three indicated sites along the western shore bank of the Rosetta area, properly marked and packed in polyethylene bags. It was cut into three parts; culm, leave and rhizome for the determination of metals in each part. Each part was washed and cleaned with tap water, oven dried at $50{ }^{\circ} \mathrm{C}$ and grinded into a powder with an electric grinder. A determined dry weight of plant organ was added to Teflon beakers and digested with $\mathrm{HNO}_{3} / \mathrm{H}_{2} \mathrm{O}_{2}(3: 1, \mathrm{v} / \mathrm{v})$ at 70 to $90^{\circ} \mathrm{C}$ during which temperature increased to about $95^{\circ} \mathrm{C}$ till evolution of nitrous gas stopped and the digest became clear. The digests were diluted with distilled water up to a known volume [19]. $\mathrm{Ni}, \mathrm{Co}$, and $\mathrm{Cr}$ were measured by AAS in $\mu \mathrm{g} \mathrm{g}^{-1}$ dry weight.

The BAF was calculated as the ratio of the element concentration in the plant tissues to the concentration of the element in the external environment. In the present investigation, the BAF was calculated using the formula outlined by Ghosh and Singh [20] as Eq. (9):

$$
B A F=\frac{C \text { plant }}{\text { Csediment }}
$$

Where $\mathrm{C}_{\text {plant }}$ and $\mathrm{C}_{\text {sediment }}$ represent the metal concentrations in the plant parts and the sediment, respectively.

\section{Pesticides analysis}

All the chemicals and solvents have a special grade for the determination of pesticide residuals. Pesticide stock standard solution was prepared by dissolving $0.1 \mathrm{~g}$ of standard in $100 \mathrm{~mL}$ pesticides quality hexane using a volumetric flask. The stock solution was transferred to a ground stoppered reagent bottle and stored in the refrigerator $(1 \mathrm{~mL}=1000 \mu \mathrm{g})$. 
Extraction of pesticides was carried out according to the Association of Official Analytical Chemists [21] and APHA [13]. OCPs were extracted from water by the liquid-liquid extraction. One liter of water samples was extracted three times with $50 \mathrm{~mL}$ portions of a mixture of $15 \%$ methylene chloride and $85 \%$ n-Hexane. The combined extracts were dehydrated by anhydrous sodium sulfate and concentrated to about $2 \mathrm{~mL}$ by evaporation under vacuum. The previously obtained extract was passed through a washed activated florisil column and eluted with $200 \mathrm{~mL}$ of $6 \%$ diethyl ether in petroleum ether at $5 \mathrm{~mL} \mathrm{~min}^{-1}$ flow rate. The eluate was concentrated to suitable volume in a rotary evaporator, after which it was dried in a test tube at $50^{\circ} \mathrm{C}$ and then was ready for gas chromatography (GC) analysis.

Before injection into GC apparatus, the dried extract was dissolved in $1 \mathrm{~mL}$-hexane of the chromatographic grade. The conditions for $\mathrm{GC}$ analysis of organochlorine pesticides were considered and GC/Mass chromatogram of standard compounds within retention time (min) is shown in the Appendix 2.

\section{Statistical analysis}

Principal component analysis (PCA) was calculated from the linear correlation matrix of the environmental variables after logarithmic transformation of the data [22]. Canonical ordination was executed using the CANOCO 4.5 package. Regression analyses were calculated to assess the heavy metal removal using $P$. australis. Further, One-way Analysis of variance (ANOVA) test was calculated between mean values of heavy metals in fresh and marine environments to test the significant differences.

\section{Results and discussion}

\section{Spatial identification of pollution sources}

The potential sources of pollution in the studied region were essentially identified and mapped using remote sensing and GIS techniques (Fig. 2). Although the urban area occupied $88.6 \mathrm{~km}^{2}(4.9 \%)$ of the total study area, several activities have been practiced within this area. Residential zones in villages and cities as well as industrial and commercial areas are examples of the activities included in the urbanized areas. These zones are scattered in separate parts along the eastern and western borders of the River Nile as well as south of the Sea coast mainly as recreational areas along the beach.

On the other hand, the agricultural zones occupy the majority of the study area. The class of the high dense vegetation occupied $48 \%\left(871.0 \mathrm{~km}^{2}\right)$ followed by the moderate density vegetation $\left(21 \%, 381.3 \mathrm{~km}^{2}\right)$ since the naturally grown plants occupy $12 \%\left(226.5 \mathrm{~km}^{2}\right)$. The irrigation and drainage canals are well distributed in the whole study area in relation with the agricultural zones as shown in Fig. 3. Total length of the irrigation canals is almost twice (1717.4 $\mathrm{km})$ of the length of the drainage canals $(954.8 \mathrm{~km})$. The

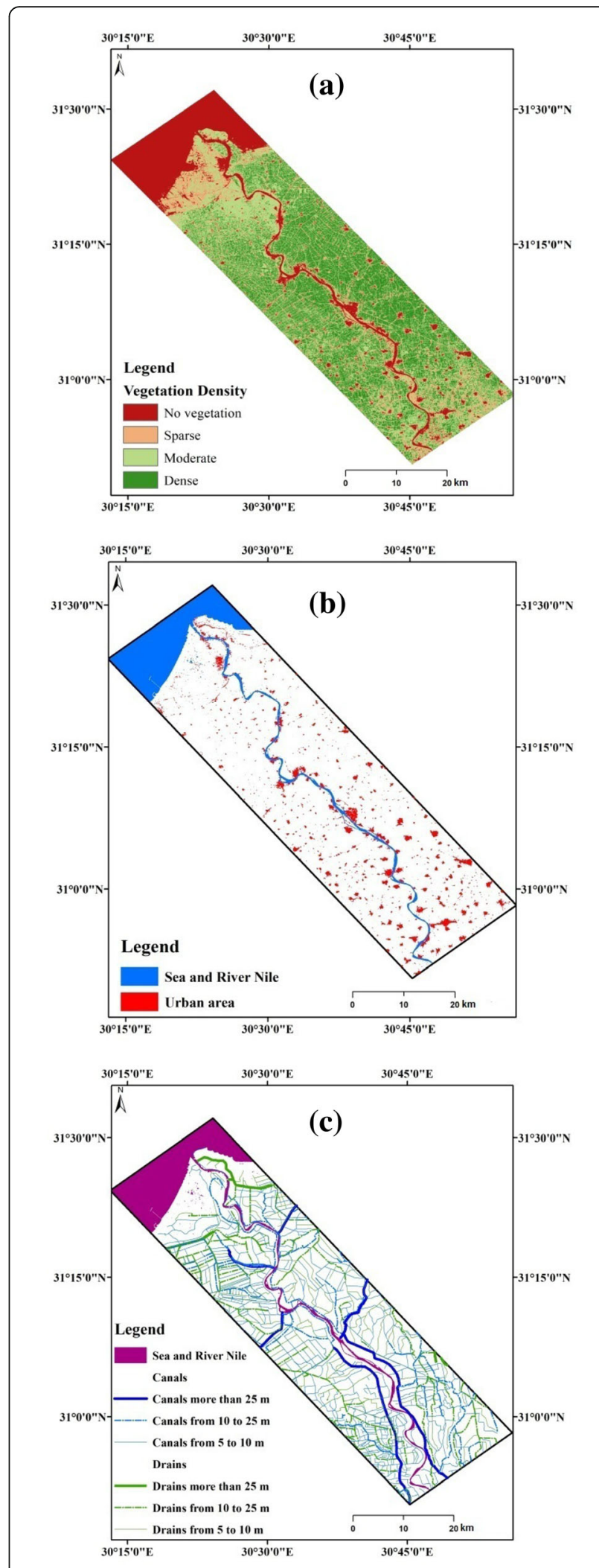

Fig. 2 Potential sources of pollution in the study area; a vegetation, b urban area, c drainage water 

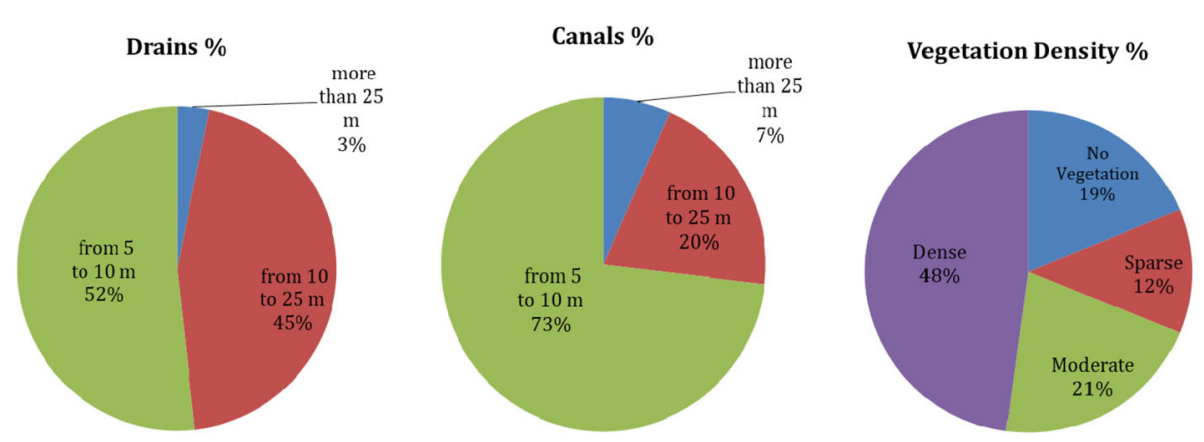

Fig. 3 Percentage of drainage network, irrigation canals and vegetation density in the study area

most common width of the canals and drains is from 5 to $10 \mathrm{~m} ; 73 \%$ (1255.6 km length) and 52\% (494.4 km length), respectively. The drainage canals $(954.8 \mathrm{~km})$, cultivations $\left(1252.4 \mathrm{~km}^{2}\right)$ and urbanized zones $\left(88.6 \mathrm{~km}^{2}\right)$ are the most significant sources of pollution in the study area which will be further discussed.

\section{Heavy metals in water, sediments and plant samples}

Heavy metal concentrations in collected samples are presented in Table 1. Results of ANOVA showed no significant difference between mean values of heavy metals in water or sediment of both studied environments except for $\mathrm{Cr}$ in sediments. Ni ranged from 0.7 to $2.7 \mu \mathrm{g} \mathrm{L}^{-1}$ and from 1.3 to
$111.5 \mu \mathrm{g} \mathrm{L}^{-1}$ with mean values of 24.5 and $1.0 \mu \mathrm{g} \mathrm{L}-1$ in fresh and marine water, respectively. The highest mean value of $\mathrm{Ni}$ was recorded at site 5 , located in the estuary, where extensive anthropogenic activities were practiced. The lowest mean value was observed in site 1 which is collected from the Seawater. Levels of $\mathrm{Ni}$ in sediments fluctuated from 15.8 to $44.8 \mu \mathrm{g} \mathrm{g}^{-1}$ and from 0 to $32.4 \mu \mathrm{g} \mathrm{g}^{-1}$ with means of

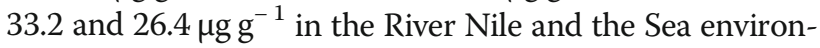
ments, respectively. The highest mean value of $\mathrm{Ni}$ in sediment was recorded at site 9 due to extensive industrial and agricultural activities. Use of agricultural fertilizers leads to higher concentrations of nickel in sediment [23]. The mean concentrations of $\mathrm{Ni}$ in sediments of the

Table 1 Concentrations of heavy metals in water and sediment of freshwater and Seawater \& One-way ANOVA between mean values of both environments

\begin{tabular}{|c|c|c|c|c|c|c|c|}
\hline \multirow[t]{2}{*}{ Site } & \multirow[t]{2}{*}{ Sample No. } & \multicolumn{3}{|c|}{ Water $\left(\mu \mathrm{g} \mathrm{L}^{-1}\right)$} & \multicolumn{3}{|c|}{ Sediment $\left(\mu \mathrm{g} \mathrm{g}^{-1}\right)$} \\
\hline & & $\mathrm{Ni}$ & $\mathrm{Co}$ & $\mathrm{Cr}$ & $\mathrm{Ni}$ & $\mathrm{Co}$ & $\mathrm{Cr}$ \\
\hline \multirow[t]{5}{*}{ Mediterranean Sea Water } & 1 & 0.7 & 2.3 & 2.7 & 20.5 & 56.8 & 79.2 \\
\hline & 2 & 0.9 & 2.5 & 3.0 & nd & nd & nd \\
\hline & 3 & 1.2 & 2.7 & 3.2 & 26.4 & 61.0 & 88.3 \\
\hline & 4 & 1.3 & 3.1 & 3.4 & 32.4 & 68.0 & 93.9 \\
\hline & Mean & 1.0 & 2.7 & 3.1 & 26.4 & 61.9 & 87.1 \\
\hline \multirow[t]{11}{*}{ River Nile Water } & 5 & 112 & 12.4 & 52.7 & 29.0 & 76.7 & 1.4 \\
\hline & 6 & 56.5 & 22.6 & 17.1 & 40.9 & 68.4 & 1.6 \\
\hline & 7 & 22.6 & 0.3 & 0.1 & 33.6 & 39.6 & 2.9 \\
\hline & 8 & 2.16 & 10.7 & 0.3 & 15.8 & 38.8 & 0.6 \\
\hline & 9 & 6.2 & 5.4 & 0.03 & 44.8 & 81.0 & 1.6 \\
\hline & 10 & 2.9 & 1.2 & 0.4 & 44.4 & 6.8 & 2.8 \\
\hline & 11 & 2.9 & 7.7 & 0.2 & 31.0 & 13.6 & 2.1 \\
\hline & 12 & 31.9 & 9.8 & 2.1 & 42.5 & 36.2 & 1.7 \\
\hline & 13 & 5.3 & 14.6 & 0.06 & 18.8 & 14.7 & 2.4 \\
\hline & 14 & 2.7 & 17.6 & 0.02 & 30.9 & 14.3 & 0.05 \\
\hline & Mean & 24.5 & 10.2 & 7.3 & 33.2 & 39.0 & 1.7 \\
\hline P-value & & 0.22 & 0.057 & 0.632 & 0.07 & 0.699 & $0.000^{* * *}$ \\
\hline
\end{tabular}


marine and the freshwater are, however, within the allowable limits $\left(75 \mu \mathrm{g} \mathrm{g}^{-1}\right)$ of EU standards [24].

Co ranged from 0.3 to $22.4 \mu \mathrm{g} \mathrm{L}^{-1}$ and from 2.3 to $3.1 \mu \mathrm{g}$ $\mathrm{L}^{-1}$ with mean values of 2.7 and $10.2 \mu \mathrm{g} \mathrm{L}^{-1}$ for fresh and marine waters, respectively. The lowest mean value was observed at site 7 which might be attributed to the lack of anthropogenic activities. In sediments, it ranged from 6.8 to $81 \mu \mathrm{g} \mathrm{g}^{-1}$ and from 57 to $68 \mu \mathrm{g} \mathrm{g}^{-1}$ with mean values of 39 and $62 \mu \mathrm{gg}^{-1}$, respectively in the two environments. The highest mean value was recorded at site 9 . This is arisen from the agricultural activities due to the usage of superphosphate fertilizers which is in agreement with El-Alfy et al. [25].

$\mathrm{Cr}$ ranged from non detectable to $52.7 \mu \mathrm{g} \mathrm{L}^{-1}$ and 2.7 to $3.4 \mu \mathrm{g} \mathrm{L}^{-1}$ with mean values of 7.3 and $3.1 \mu \mathrm{g} \mathrm{L}^{-1}$ for fresh and marine waters, respectively. The highest mean value of $\mathrm{Cr}$ was recorded at the end of the River branch. This is probably because this area is characterized by extensive activities mainly from the agricultural sector. However, the concentrations of $\mathrm{Cr}$ are within water quality guidelines for the protection of the aquatic life [26]; $8.9 \mu \mathrm{g} \mathrm{L}^{-1}$ for freshwater and $56 \mu \mathrm{g} \mathrm{L}^{-1}$ for marine water. Cr in sediments fluctuated from 0.05 to $2.9{\mu \mathrm{gg}^{-1}}^{-1}$ and from 79 to $94 \mu \mathrm{g} \mathrm{g}^{-1}$ with mean values of 1.7 and $87 \mu^{-1} g^{-1}$, for fresh and marine environments, respectively. The highest concentration of $\mathrm{Cr}$ was recorded at site 4 in the marine environment which might be attributed to the runoff from corrosion of painted surfaces, industrial activities, decorative trims, tar and automotive tire of navigation activities in the Sea [27]. The mean concentrations of $\mathrm{Cr}$ in sediments are within the $\mathrm{EU}$ acceptable limits $\left(150 \mu \mathrm{g} \mathrm{g}^{-1}\right)$ [24]. The order of metals in water and sediments of the River Nile is $\mathrm{Ni}>\mathrm{Co}>\mathrm{Cr}$, which is reversed in the Sea water and the order in the Sea sediments is $\mathrm{Cr}>\mathrm{Co}>\mathrm{Ni}$.

Considering the evaluation for drinking and possible health effects modified after WHO [26] for Co and Cr, the recorded values are within the permissible limits $\left(100 \mu \mathrm{g} \mathrm{L}^{-}\right.$

$\left.{ }^{1}\right)$. However, for $\mathrm{Ni}\left(20 \mu \mathrm{g} \mathrm{L}^{-1}\right)$, its levels fluctuated from low to very high levels within the studied locations. High concentrations of Ni may be carcinogenic, and may also cause allergies and skin problems [27]. On the other hand, the highest mean concentration of $\mathrm{Ni}$ was recorded at culm of $P$. australis while in case of $\mathrm{Co}$ in the root of the plant (Fig. 4).

PCA of heavy metals in water and sediments of the River Nile and the Sea is shown in Fig. 5. The values indicated that $\mathrm{Cr}, \mathrm{Ni}$ and $\mathrm{Co}$ in water as well as $\mathrm{Ni}$ in sediments are mostly related to the sites of freshwater ecosystem. These sites are highly impacted by point and non-point sources of pollution which are distributed along the study area. However, $\mathrm{Cr}$ in sediment showed a significant correlation within sites of the Mediterranean Sea.

Table 2 shows that the calculated HPI (98) is lower than the critical pollution value (100) and the result obtained by El-Ameir [28]. Water quality and its

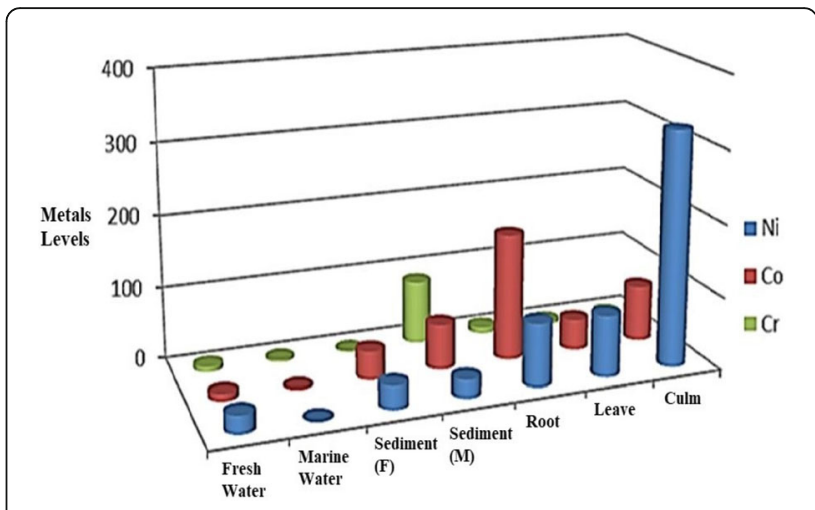

Fig. 4 Mean concentrations of heavy metals ( $\mu \mathrm{g} \mathrm{L}^{-1}$ and $\mu \mathrm{g} \mathrm{g}^{-1}$ ) within different environmental components

suitability for drinking purposes are examined by determining the MI [29]; the MI for the freshwater sites of the Rosetta River Nile indicated that water is moderately affected by pollution.

The ecological risk of metals in all sites of the studied environments is in low potential ecological risk category $(<40)$. Likewise, values of Ei recorded low ecological risk as illustrated in Table 3. On the other hand, PLI values (1.2) indicated pollution of the marine environment, while in freshwater it was less than 1 (non-significant impact). Abd El-Hamid et al. [30] stated that PLI values decrease with increasing the distance from sources of pollution. The risk index of metals showed high values in coastal marine water and nearby estuary. However, the lowest concentration of RI was observed at site 10 (freshwater) (Table 3).

The toxicity of the three metals $(\mathrm{Ni}, \mathrm{Co}$, and $\mathrm{Cr})$ was evaluated in $P$. australis. Phragmites is a common weed present in most of the studied sites along the Rosetta

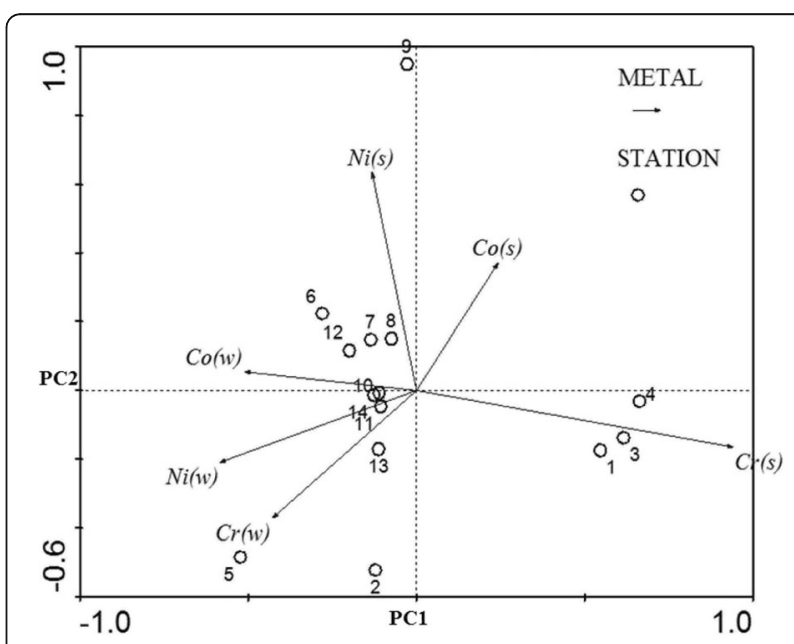

Fig. 5 PCA for heavy metals in water and sediments among different sites 
Table 2 Heavy metal pollution index (HPI) and metal index (MI) in freshwater of Rosetta branch

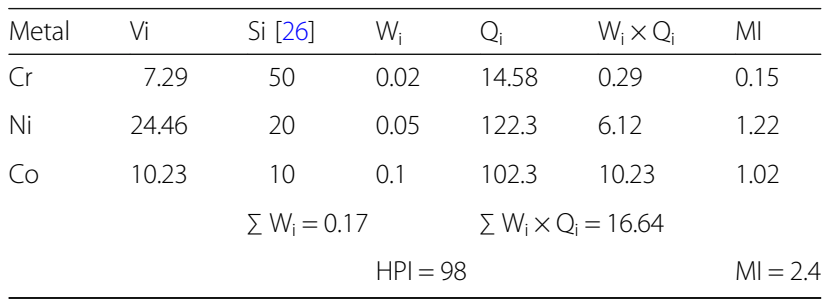

Where $\mathrm{V}_{\mathrm{i}}$ : the value of the metal, $\mathrm{S}_{\mathrm{i}}$ : standard value, $\mathrm{W}_{\mathrm{i}} ;$ Weightage value and $\mathrm{Q}_{\mathrm{i}}$ : quality rating

River Nile. Further, it can grow in wastewater sites and has the ability to accumulate different pollutants. Levels of the metals in different parts of the plant are presented in Table 4. The lowest concentration of $\mathrm{Ni}$ was observed at the plant leaves at site (2), while the highest value was recorded at culm of the plant at site 1 $\left(174 \mu^{g^{-1}}\right)$. For $\mathrm{Co}$, the lowest value was recorded at leaves of the plant collected from site $2\left(1.3 \mu \mathrm{g} \mathrm{g}^{-1}\right)$, while the highest value was recorded at the plant roots at site (2) amounting $323 \mu \mathrm{gg}^{-1}$. For Cr, the lowest value was recorded at culm of site 3 while the highest value was recorded in the plant root at site $2\left(17 \mu \mathrm{g} \mathrm{g}^{-}\right.$ $\left.{ }^{1}\right)$. The total concentrations of $\mathrm{Ni}$ in the whole plant at different sites follow the order; site $1>$ site $2>$ site 3 ; for $\mathrm{Co}$; site $2>$ site $1>$ site 3 , and for $\mathrm{Cr}$; site $2>$ site $3>$ site 1 . This is due to the severity and the different types of activities from site to site. The mean concentration of these metals in the plant is more than the critical range reported by Kabata-Pendias [31].

Table 3 Ecological Risk (Er), Risk Index (RI) and Pollution Load Index (PLI) in the sediment of freshwater and marine environments

\begin{tabular}{lllllll}
\hline Site & Location & & $\mathrm{Er}$ & \multicolumn{5}{c}{$\mathrm{Rl}$} & $\mathrm{PLI}$ \\
\cline { 3 - 5 } & & $\mathrm{Ni}$ & $\mathrm{Co}$ & $\mathrm{Cr}$ & & \\
\hline Mediterranean Sea Water & 1 & 1.5 & 15.0 & 1.8 & 18.2 & 0.9 \\
& 2 & - & - & - & - & - \\
River Nile Water & 3 & 1.9 & 16.1 & 2.0 & 20.0 & 1.1 \\
& 4 & 2.4 & 17.9 & 2.1 & 22.4 & 1.2 \\
& 5 & 2.1 & 20.2 & 0.03 & 22.4 & 0.3 \\
& 6 & 3.0 & 18 & 0.04 & 21.1 & 0.3 \\
& 7 & 2.5 & 10.4 & 0.06 & 13.0 & 0.3 \\
& 8 & 1.2 & 10.2 & 0.01 & 11.4 & 0.2 \\
& 9 & 3.3 & 21.3 & 0.04 & 24.6 & 0.4 \\
& 10 & 3.3 & 1.8 & 0.06 & 5.1 & 0.2 \\
& 11 & 2.3 & 3.6 & 0.05 & 5.9 & 0.2 \\
& 12 & 3.1 & 9.5 & 0.04 & 12.6 & 0.3 \\
& 13 & 1.4 & 3.9 & 0.05 & 5.3 & 0.2 \\
& 14 & 2.3 & 3.8 & 0 & 6.0 & 0.06 \\
\hline
\end{tabular}

BAF was calculated for $P$. australis to assess its potentiality for the removal of toxic metals from the surrounding environment. The order of metal BAF results is site specific, or $\mathrm{Ni}>\mathrm{Co}>\mathrm{Cr}$ in site $1, \mathrm{Co}>\mathrm{Cr}>\mathrm{Ni}$ in site 2 , and $\mathrm{Ni}>\mathrm{Cr}>\mathrm{Co}$ in site 3 .

Correlation coefficient was calculated using Microsoft Excel data analyses tool incorporating the original data based on metal concentration in sediments and in different parts of the plant. Significant correlations were observed between; $\mathrm{Ni}$ (root) \& $\mathrm{Ni}$ (sediment) $\left(R^{2}=\right.$ 0.9995), Co (leaves) \& Co (sediment) $\left(R^{2}=0.932\right)$ and $\mathrm{Cr}$ (leaves) \& $\mathrm{Cr}$ (sediment) $\left(R^{2}=0.8445\right)$. Regression analyses confirmed that $P$. australis plant, particularly its roots and leaves, can be used for the removal of heavy metals from wastewater.

\section{Organochlorine pesticides in water and sediment}

Although industrial and agricultural activities were concentrated in some parts of the study area, organochlorine pesticides levels were below the detection limits of the method used for OCP residues extraction, which is $0.005 \mathrm{mg} \mathrm{L}^{-1}$ for water and $0.005 \mathrm{mg} \mathrm{kg}^{-1}$ for sediment. The safe limits identified in WHO [32] and Egyptian Ministry of Health [33] for water and sediments are shown in Appendix 3. The non-detection of OCPs in the collected water and sediments may be attributed to that the samples were collected during summer months with high temperature $\left(30^{\circ} \mathrm{C}\right)$ at which pesticides are unstable in water, and the hydrolyzing rate increases with increasing temperature [34]. Moreover, the volatility properties of organochlorine pesticides may cause their loss into the atmosphere during transport far from their sources [35]. The results are in accordance with El-Barbary et al. [36] who recorded zero OCP levels in water and sediment samples collected from the Rosetta area. The present results are consistent with the findings of El-Ezaby et al. [37] who revealed that the analyzed OCP residues were not detected in water samples during the summer season.

Rand et al. [38] have mentioned that some pesticides break down quickly in the environment, whereas others persist over longer periods of time and can accumulate or transform into contaminant by-products. In addition to movement through soil, pesticides can be mobilized by precipitation and wind. In contrast, El-Gendy et al. [39] analyzed residues of organochlorine insecticides in water and indicate that the Rosetta branch was more polluted than the Damietta branch and added that p,p'-DDE, and $\gamma$-hexachlorocyclohexane $(\mathrm{HCH})$ isomers dominated the DDTs and $\mathrm{HCH}$ distributions at the studied locations. Said et al. [5] investigated the concentrations of chlorinated hydrocarbons and found that their concentrations decrease in the order of PCBs $>$ DDTs $>$ Transchlordane 
Table 4 Concentrations of heavy metals in leave, culm, and roots of $P$. australis within sites of the study area compared with normal and critical ranges in plants [31] and Bioaccumulation Factor of the plant (BAF)

\begin{tabular}{|c|c|c|c|c|}
\hline \multirow[t]{2}{*}{ Site } & \multirow[t]{2}{*}{ Plant parts } & \multicolumn{3}{|c|}{ Metal $\left(\mu \mathrm{g} \mathrm{g}^{-1}\right)$} \\
\hline & & $\mathrm{Ni}$ & Co & $\mathrm{Cr}$ \\
\hline \multirow{6}{*}{$\begin{array}{l}\text { Site_1 } \\
\text { (near Sea-Mahmodia) }\end{array}$} & Leave & 104 & 61 & 3.6 \\
\hline & Culm & 174 & 47 & 0.9 \\
\hline & Root & 88 & 26 & 0.4 \\
\hline & Mean (Plant) & 122 & 45 & 1.6 \\
\hline & Mean (Sediment) & 30 & 56 & 1.7 \\
\hline & BAF & 4.1 & 0.8 & 1.0 \\
\hline \multirow{6}{*}{$\begin{array}{l}\text { Site_2 } \\
\text { (Desouk-Kafr Elsheikh boundary) }\end{array}$} & Leave & 42 & 1.3 & 3.3 \\
\hline & Culm & 67 & 154 & 8.4 \\
\hline & Root & 86 & 323 & 17 \\
\hline & Mean (Plant) & 65 & 159 & 9.4 \\
\hline & Mean (Sediment) & 40 & 34 & 2.2 \\
\hline & BAF & 1.6 & 4.7 & 4.3 \\
\hline \multirow{6}{*}{$\begin{array}{l}\text { Site_3 } \\
\text { (Kafr Elsheikh boundary-Kafr Elzayat) }\end{array}$} & Leave & 107 & 65 & 6.9 \\
\hline & Culm & 83 & 31.44 & 0.2 \\
\hline & Root & $\mathrm{Nd}$ & nd & $\mathrm{Nd}$ \\
\hline & Mean (Plant) & 95 & 48 & 3.6 \\
\hline & Mean (Sediment) & 31 & 23 & 1.4 \\
\hline & BAF & 3.1 & 2.2 & 2.6 \\
\hline \multicolumn{2}{|l|}{ Normal Range in Plants (ppm) } & $0.1-5$ & $0.02-1$ & - \\
\hline \multicolumn{2}{|l|}{ Critical Range in Plants (ppm) } & $10-100$ & $15-50$ & - \\
\hline
\end{tabular}

$>\mathrm{HCH}$ for all water samples collected from Lake Burullus. Further, sediment samples were found containing high levels of organochlorine pesticide residues.

Ramadan et al. [40] demonstrated that high concentrations of DDTs, chlordane, chlorpyrifos, and $\mathrm{HCHs}$ were recorded in sediments along the Mediterranean Sea coast between Alexandria and Port Said City. Other pesticides (dieldrin, aldrin, endosulfane, heptachlor, and its epoxides) were detected in the sediments but at lower concentrations. In surface fresh and groundwater systems, organochlorine pesticides may also enter the drinking water supplies [41].

\section{Conclusions}

The present study discusses two different contaminants (i.e. toxic heavy metals and pesticides) that threat aquatic fresh and marine environments using an integrated approach incorporating field survey and lab analyses with space-borne technology and geospatial analyses. Surface water, bottom sediments, and $P$. australis were collected and investigated for their metal and organochlorine pesticide content. Integrating satellite imagery with GIS was successful to map the potential pollution sources in the investigated area. Wastewater discharge, agricultural practices, and urban activities were identified as the most significant sources of pollution in the Rosetta area. It can be concluded that the study area is moderately affected by heavy metal pollution according to MI values in water. Organochlorine pesticide residues in water and sediment were found below detection limits $\left(5 \mu \mathrm{g} \mathrm{L}^{-1}\right.$ and $\left.5 \mu \mathrm{g} \mathrm{kg}^{-1}\right)$ for water and sediment, respectively.

Regression analyses showed that $P$. australis (particularly leave and root) can be used in the remediation process for removal of heavy metals from wastewater. Therefore, the present study recommended using $P$. australis as potential phytoremediator for removal of metals. Further, the present study highly recommends;

- Using the massive community educational program to minimize pollution.

- Treating industrial, domestic and agricultural wastewaters before discharging into waterways.

- Promoting and encouraging the biological treatment processes such as using the naturally grown plants like $P$. australis in the contaminated sites. 


\section{Appendix 1}

Table $\mathbf{5}$ Description of metal indices being used in this study

\begin{tabular}{|c|c|c|}
\hline Index & Value & Category \\
\hline \multirow[t]{4}{*}{$\mathrm{CF}$} & $<1$ & Low contamination \\
\hline & $1 \leq C F<3$ & Moderate contamination \\
\hline & $3 \leq C F<6$ & Considerable degree of contamination \\
\hline & $C F \geq 6$ & Very high contamination \\
\hline \multirow[t]{2}{*}{ PLI } & $<1$ & No Pollution \\
\hline & $>1$ & Polluted \\
\hline \multirow[t]{5}{*}{ Er } & $<40$ & Low potential ecological risk \\
\hline & $40 \leq \mathrm{Er}<80$ & Moderate potential ecological risk \\
\hline & $80 \leq \mathrm{Er}<160$ & Considerable potential ecological risk \\
\hline & $160 \leq \mathrm{Er}<320$ & High potential ecological risk \\
\hline & $E r \geq 320$ & Very high ecological risk \\
\hline \multirow[t]{4}{*}{$\mathrm{Rl}$} & $<150$ & Low ecological risk \\
\hline & $150 \leq \mathrm{Rl}<300$ & Moderate ecological risk \\
\hline & $300 \leq \mathrm{Rl}<600$ & Considerable ecological risk \\
\hline & $\mathrm{Rl}>600$ & Very high ecological risk \\
\hline \multirow[t]{6}{*}{ Ml } & $<0.3$ & Very Pure \\
\hline & $0.3 \leq \mathrm{Ml}<1$ & Pure \\
\hline & $1 \leq \mathrm{Er}<2$ & Slightly Affected \\
\hline & $2 \leq \mathrm{Er}<4$ & Moderately Affected \\
\hline & $4 \leq \operatorname{Er}<6$ & Strongly Affected \\
\hline & $>6$ & Seriously Affected \\
\hline
\end{tabular}

Where CF Contamination Factor, PLI Pollution Load Index, Er Ecological Risk, MI Metal Index and RI Risk Index

\section{Appendix 2}

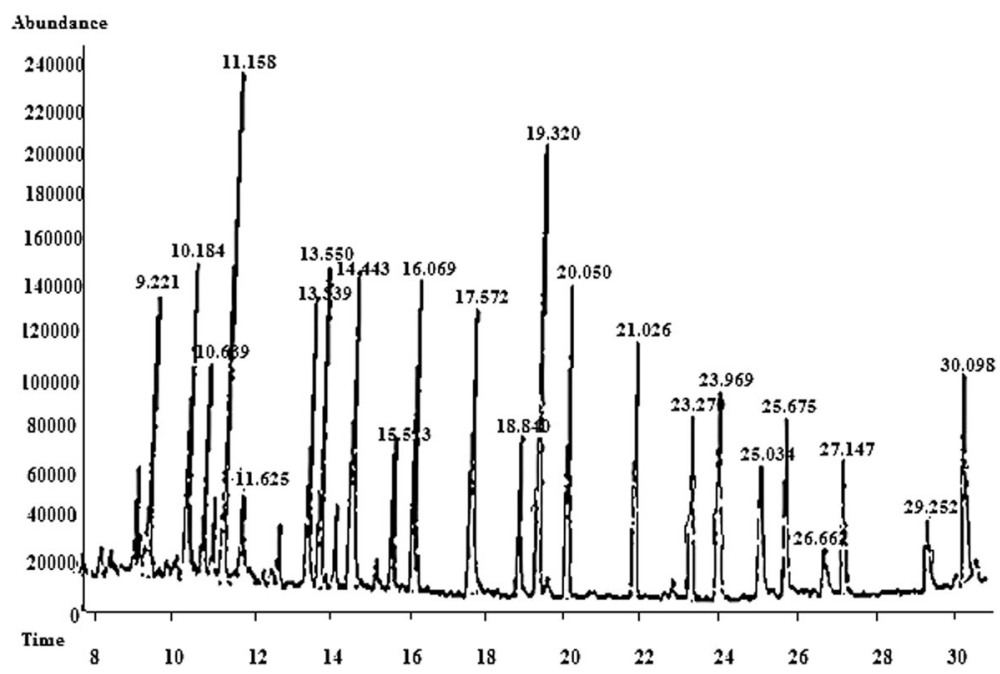

Fig. 6 GC/Mass Chromatogram of standard compounds. Retention Times (min): a- HCH (9.09); $\beta$ - HCH (10.12); Quintozene (10.50); Chlorothionil (11.69); Chlorpyrifos-Me (13.19); Heptachlor (13.44); 4,4-Dichlorobenzophenone (14.38); Chlorpyrifos (15.87); Cyprodinil, (17.47); Chlorodane-Gamma (19.07); a-endosulfane (19.82); Dieldrin (21.54); Endrin (22.981); $\beta$-endosulfane (23.683); p,p-DDD (24.802); endosulfane Sulfate (26.855); piperonylbutoxide (29.93) and methoxychlor (32.27) 


\section{Appendix 3}

Table 6 World Health Organization, Egyptian Standards and British Environmental Quality Standards for OCPs in drinking water

\begin{tabular}{llll}
\hline OCPs & $\begin{array}{l}\text { Maximum Allowable } \\
\text { Level }\left(\mu \mathrm{L} \mathrm{L}^{-1}\right) \\
{[32]}\end{array}$ & $\begin{array}{l}\text { Maximum Allowable } \\
\text { Level }(\mu \mathrm{g} \mathrm{L}) \\
{[33]}\end{array}$ & $\begin{array}{l}\text { British Environmental } \\
\text { Standards }\left(\mu \mathrm{g} \mathrm{L}^{-1}\right) \\
{[42]}\end{array}$ \\
\hline Dieldrin & 0.03 & 0.03 & 0.01 \\
Endrine & - & - & 0.005 \\
Lindane & 2.0 & 1.0 & - \\
Heptachlor & 0.1 & - & - \\
Chlorodane & - & 0.2 & - \\
Methoxychlor & - & 20.0 & - \\
\hline
\end{tabular}

\section{Acknowledgments}

Authors acknowledge ESRI and the United States Geological Survey (http:// glovis.usgs.gov/) for supporting satellite images and software. Thanks are extended to Dr. A.Z. Abotalib, University of Southern California (USC), USA for his kind help and support during the paper revision.

\section{Authors' contributions}

All authors proposed the study and participated in writing the manuscript. MAE, HTA and AME carried out the field survey and collected the samples. MAE and HTA analyzed the heavy metals content in the collected water, sediment and plants samples while AFH carried out the organochlorine pesticide investigations. AME performed the remotely sensed data and GIS analysis while MAE carried out the statistical analysis. AME and MAE revised and corrected the manuscript. All authors read and approved the final manuscript.

\section{Competing interests}

The authors declare that they have no competing interests

\section{Author details}

${ }^{1}$ Marine Pollution Department, National Institute of Oceanography and Fisheries, Alexandria 21556, Egypt. 'Environmental Sciences Department, Faculty of Sciences, Damietta University, New Damietta 34517, Egypt. ${ }^{3}$ Environmental Studies Department, National Authority for Remote Sensing and Space Sciences, Cairo 1564, Egypt.

\section{Received: 13 April 2018 Accepted: 14 May 2019}

\section{Published online: 17 July 2019}

\section{References}

1. Zahran MA, Willis AJ. Plant life in River Nile in Egypt. Riyadh: Mars Publishing House; 2003.

2. Wahaab RA, Badawy MI. Water quality assessment of the River Nile system: an overview. Biomed Environ Sci. 2004;17:87-100.

3. Santos IR, Silva-Filho EV, Schaefer CEGR, Albuquerque MR, Campos LS Heavy metal contamination in coastal sediments and soils near the Brazilian Antarctic Station, King George Island. Mar Pollut Bull. 2005;50:185-94.

4. Yang YQ, Chen FR, Zhang L, Liu JS, Wu SJ, Kang ML. Comprehensive assessment of heavy metal contamination in sediment of the Pearl River estuary and adjacent shelf. Mar Pollut Bull. 2012;64:1947-55.

5. Said TO, El Moselhy KM, Rashad AAM, Shreadah MA. Organochlorine contaminants in water, sediment and fish of Lake Burullus, Egyptian Mediterranean Sea. B Environ Contam Tox. 2008:81:136-46.

6. Mansour SA. Persistent organic pollutants (POPs) in Africa: Egyptian scenario. Hum Exp Toxicol. 2009;28:531-66.

7. El-Zeiny A, El-Kafrawy S. Assessment of water pollution induced by human activities in Burullus Lake using Landsat 8 operational land imager and GIS. Egypt J Remote Sens. 2017;20:S49-56.

8. Roberts AD, Prince SD. Effects of urban and non-urban land cover on nitrogen and phosphorus runoff to Chesapeake Bay. Ecol Indic. 2010; 10:459-74.
9. Elhaddad E, Al-Zyoud S. The quality assessment of pollution of Rosetta branch, Nile River, Egypt. Arab J Geosci. 2017;10:97.

10. Mostafa M, Peters RW. A comprehensive assessment of water quality at the Rosetta branch of the Nile River, Egypt. J Civ Eng Archit. 2016;10:513-29.

11. El-Zeiny AM, Abd El-Hamid HT, El-Alfy MA. Anthropogenic impacts on water quality of River Nile and marine environment, Rosetta branch using geospatial analyses. J Environ Sci. 2018;47:89-101.

12. Ezzat $S M$, Mahdy HM, Abo-State MA. Water quality assessment of River Nile at Rosetta branch: impact of drains discharge. Middle-E J Sci Res. 2012;12:413-23.

13. APHA. Standard methods for the examination of water and wastewater. 18th ed. Washington, DC: American Public Health Association; 1992.

14. Zhu W, Bian B, Li L. Heavy metal contamination of road-deposited sediments in a medium size city of China. Environ Monit Assess. 2008;147:171-81.

15. Caeiro S, Costa MH, Ramos TB, Fernandes F, Silveira N, Coimbra A, et al. Assessing heavy metal contamination in Sado estuary sediment: an index analysis approach. Ecol Indic. 2005;5:151-69.

16. Bakan $\mathrm{G}$, Ozkoc $\mathrm{HB}$, Tulek $\mathrm{S}$, Cuce $\mathrm{H}$. Integrated environmental quality assessment of Kizilirmak River and its coastal environment. Turk J Fish Aquat Sc. 2010;10:453-62.

17. Oregioni $B$, Astone SR. The determination of selected trace metals in marine sediments by flameless/flame-atomic absorption spectrophotometry. Monaco: International Atomic Energy Agency - Environment Laboratories; 1984.

18. Hakanson L. An ecological risk index for aquatic pollution control. A sedimentological approach. Water Res. 1980;14:975-1001.

19. Allen SE, Grimshaw HM, Parkinson JA, Quarmby C, Roberts JD. Chemical analysis of ecological materials. Oxford: Blackwell Scientific Publications; 1974.

20. Ghosh M, Singh SP. A comparative study of cadmium phytoextraction by accumulator and weed species. Environ Pollut. 2005;133:365-71.

21. AOAC. Arlington: the association of official analytical chemists. In: Official methods of analysis. 15th ed; 1990

22. Sousa SIV, Martins FG, Alvim-Ferraz MCM, Pereira MC. Multiple linear regression and artificial neural networks based on principal components to predict ozone concentrations. Environ Model Softw. 2007:22:97-103.

23. McGrath SP. Chromium and nickel. In: Alloway BJ, editor. Heavy metal in soils. 2nd ed. London: Blackie Academic and Professional; 1995. p. 152-78.

24. EC. Heavy metals in wastes. Brussels: European Commission; 2002.

25. El-Alfy MA, El-Amier YA, El-Hamid HTA. Soil quality and health risk assessment of heavy metals in agricultural areas irrigated with wastewater from Kitchener drain, Nile Delta, Egypt. J Sci Agric. 2017;1:158-70.

26. WHO. Guidelines for drinking-water quality. 3rd ed. Geneva: World Health Organization; 2006.

27. Pawlisz AV, Kent RA, Schneider UA, Jefferson C. Canadian water quality guidelines for chromium. Environ Toxic Water. 1997;12:123-83.

28. El-Ameir YA. Evaluation of heavy metal pollution in Damietta branch of Nile River, Egypt using metal indices and phyto-accumulators. J Environ Sci. 2017;46:89-102.

29. Prasad B, Sangita K Heavy metal pollution index of ground water of an abandoned open cast mine filled with fly ash: a case study. Mine Water Environ. 2008:27:265-7.

30. Abd El-Hamid HT, Hegazy TA, Ibrahim MS, El-Moselhy KM. Assessment of heavy metals pollution in marine sediments along the Mediterranean Sea, Egypt. J Geogr Env Earth Sci Int. 2016;7:1-11. 
31. Kabata-Pendias A. Trace elements in soils and plants. 3rd ed. Boca Raton: CRC Press; 2011

32. WHO. Guidelines for drinking-water quality. Geneva: World Health Organization; 1984.

33. EMH. Standards and specifications of water quality for drinking and domestic uses. Cairo: Egyptian Ministry of Health; 2007.

34. Howard PH. Handbook of environmental fate and exposure data for organic chemicals. Volume III. Pesticides. Chelsea: Lewis Publishers; 1991.

35. Ritter LR, Solomon KR, Forget J, Stemeroff M, O'leary CO. Persistent organic pollutants. An assessment report on: DDT-aldrin-dieldrin-endrin-chlordane heptachlor-hexachlorobenzene mirex-toxaphene polychlorinated biphenyls dioxins and furans prepared. Geneva: The International Programme on Chemical Safety; 2001.

36. El-Barbary AA, Yehia MM, El-Bouraie MM. Evaluation of organochlorine pesticides (ocps) in surface water and bed sediment samples from of the River Nile at Rosetta branch, Egypt. J Appl Sci Res. 2008:4:1985-93.

37. El-Ezaby KH, Ibrahem MS, Abdo AF. Monitoring of some pesticides in Nile River - Damietta. Mansoura J Biol. 2009;36:145-60.

38. Rand GM, Wells PG, Mclarty LS. Fundamentals of aquatic toxicology: effects, environmental fate, and risk assessment. In: Rand GM, editor. Introduction to aquatic toxicology. Washington, DC: Taylor and Francis; 1995. p. 3-66.

39. El-Gendy KS, Abdalla AA, Aly HA, Tantawy G, Elsebae AH. Residue levels of chlorinated hydrocarbon compounds in water and sediment samples from Nile branches in the Delta, Egypt. J Environ Sci Health B. 1991;26:15-36.

40. Ramadan AA, Salama MH, Monged MH. Assessment of radiological and chemical pollutants and their effects on the marine ecosystems along the Mediterranean Sea coast between Alexandria and Port Said City - Egypt. Arab J Nucl Sci Appl. 2017;50:131-6.

41. Hasballah FA. Studies on some physiological parameters and environmental planning of some toxins in Damietta governorate [Master's thesis]. Mansoura: Mansoura Univ; 2008.

42. Gray NF. Water technology: an introduction for environmental scientists and engineers. 3rd ed. Oxford: Butterworth-Heinemann; 2010.

\section{Publisher's Note}

Springer Nature remains neutral with regard to jurisdictional claims in published maps and institutional affiliations.

Ready to submit your research? Choose BMC and benefit from:

- fast, convenient online submission

- thorough peer review by experienced researchers in your field

- rapid publication on acceptance

- support for research data, including large and complex data types

- gold Open Access which fosters wider collaboration and increased citations

- maximum visibility for your research: over $100 \mathrm{M}$ website views per year

At $\mathrm{BMC}$, research is always in progress.

Learn more biomedcentral.com/submissions 